\title{
A new record of rhamphocelus carbo (pallas, 1764) consuming pagamea guianensis aubl
}

\begin{abstract}
White-sand vegetation occupies about $7 \%$ of the Amazon and their largest extension occurs in the Rio Negro basin. Campinas and campinaranas, are shrub and forest vegetation types characterized by sandy, poor in nutrients soil, and present high endemism in both plant and animal species. Among the plant species that are restricted to the areas of campina and campinarana is Pagamea guianensis Aubl, a dioecious shrub with annual flowering cycle. In tropical forests, birds play an important role for seed dispersal. Here we identified Rhamphocelos carbo (Ave: Thraupidade) as a consumer and possible disperser of P. guianensis. Birds consumed the whole fruit and seeds and then defecate the seeds intact.
\end{abstract}

Keywords: birds, fruit dispersal, campinarana, white sand, frugivory
Volume 3 Issue 2 - 2018

\author{
Jhennyffer de MAlves,' Cintia Cornelius, ${ }^{2}$ \\ Veridiana $\vee$ Scudeller ${ }^{2}$ \\ 'Pós-graduação em Diversidade Biológica, Federal University of \\ Amazonas UFAM, Brazil \\ ${ }^{2}$ Department of Biology, Federal University of Amazonas- UFAM, \\ Brazil
}

Correspondence: Jhennyffer de M Alves, Federal University of Amazonas UFAM, Brazil,Tel 559282575379 ,

Email jhemalves@gmail.com

Received: March 02, 2018 | Published: April 05, 2018

\section{Introduction}

White sand-vegetation is patchily distributed across the Amazon and characterized by open vegetation (Campinas) and low-canopy forests (campinaranas). These plant formations occupy about $7 \%$ of the Amazon ${ }^{1}$ and their greatest extent is found in the Rio Negro basin. ${ }^{2}$ They are characterized by sandy, poor in nutrients soils, with poor drainage, very low fertility and a scleromorphic physiognomy, with a high number of endemic plant species. The plant genus Pagamea Aubl is common and restricted to white-sand vegetation patches. ${ }^{3}$ It includes dioecious species, distylic and homostylic, with little floral morphological variation between them. Fleshy fruits have evolved independently at least 12 times in the Rubiaceae. ${ }^{4}$ Most of these appear to have originated during the Eocene to Oligocene, i.e. the radiation period for some animal taxa (birds and mammals) comprising most extant dispersers of Rubiaceae fruits. ${ }^{4}$ Pagamea guianensis Aubl., is inserted in the clade guianensis, the most diversified and widely distributed, where all species are dioceses, with sessile flowers. ${ }^{3} \mathrm{We}$ observed that the flowering occurs from December to May, with greater intensity in February, the fruiting begins in February with maturity in June. Fruits are indehiscent, drupe type with ellipsoid seed.

Communities of birds in white sand vegetation are characterized by low number of species when compared to terra firme forests, with high level of endemism, ${ }^{5-7}$ a distinctive species composition ${ }^{8}$ and with a number of species that regularly consume fruits. Seed dispersal is the process where seeds are taken to distances considered safe from the parent plant, where competition and predation may theoretically be smaller.,10 In tropical forests, animal-mediated dispersal is very common ${ }^{11,12}$ and birds play a very important role among dispersing vertebrates because of their abundance, frequency of feeding on fruits, variety of seed sizes that they can ingest and by enabling long distance dispersal. ${ }^{13,14}$ In campinas and campinaranas, seed dispersal by birds may play an important role due to the patchy distribution of these habitats, but very little information exists to date about this process. Thus, in this note we report on consumers and possible dispersers of $P$. guianensis. The study area is located near Iranduba, ca. $10 \mathrm{~km}$ from the Rio Negro bridge, that connects Manaus to other cities to the south-west, on the secondary road Lago do Janauari, Community Vale do Amanhecer (2'11'52.5'S, 6007'02.8”'W;) (Figure 1). The vegetation type is grassy-woody campina, surrounded by arboreous campinarana. The study site is located in a new urban expansion area with considerable recent landscape change. We obtained information on fruit consumers and possible dispersers of $P$. guianensis with focal observations and video records conducted in July 2015. A total of 32 hours of observation were done. Five 12-m mist-nets were operated close to the recording sites during one morning in April 2016 (6:0011:00), captured birds were banded and released immediately. During our video or focal observations we recorded a single bird species, Rhamphocelus carbo (Pallas, 1764) (Ave: Thraupidade), silverbeaked Tanager, consuming fruits of $P$. guianensis. They foraged in groups of males and females for two to three minutes. With mistnets we captured five $R$. carbo individuals (2 females and 3 males). During handling, we observed that they had consumed the whole fruits and seeds, as they defecated $P$. guianensis seeds intact (Figure 2). Ramphocelus carbo presents a marked sexual dimorphism. The female has a dark brown forehead and back, wings and a pure black tail; abdomen, flanks and rust-brown uropyge; the jaw is black. ${ }^{15}$ The male features are the purple head and chest, blackened wings and tail, the upper and black beak, and the lower beak is whitish in color. The species is usually found in small groups frequently with predominance of males and females and a few juveniles, they are omnivorous, foraging insects and fruits. ${ }^{16,17}$ This species is common in forest and shrubby habitats and is also frequent in human-modified landscapes. ${ }^{17}$ Males in the breeding season exhibit territoriality using an early morning chorus which means that their breeding ground goes up to a $10 \mathrm{~m}$ radius. ${ }^{16}$ 


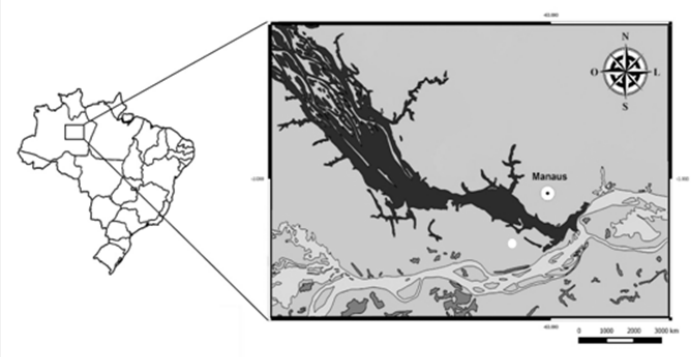

Figure I Study area, a campinarana localized in the community Vale do Amanhecer (white point), city of Iranduba,Amazonas.

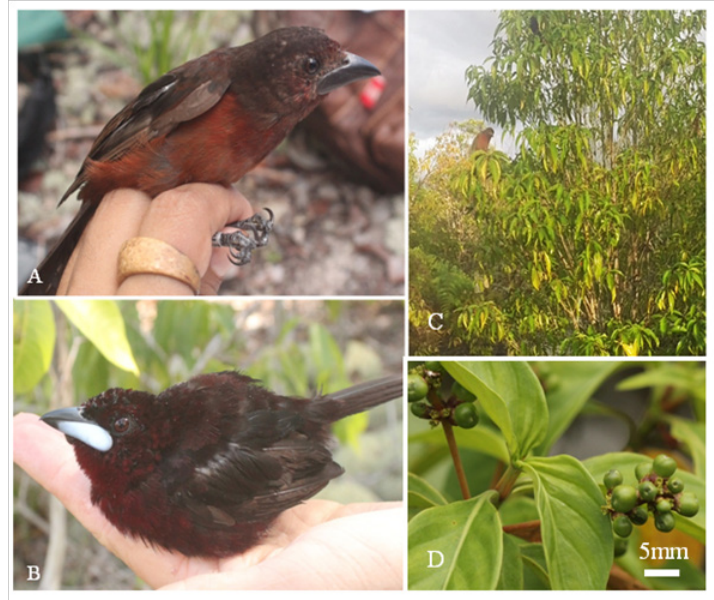

Figure 2 Ramphocelus carbo, possible disperser of $P$. guianensis.
A. Female
B. Male
C. R. carbo visiting Pagamea guianensis
D. Drupe fruits of P. guianensis

\section{Discussion}

Rhamphocelus carbo, locally known as "pipira-vermelha", ${ }^{15}$ was the only species observed consuming the fruits of Pagamea guianensis in our study area. Ramphocelos carbo is a species widely distributed in the Amazon and commonly observed in secondary forests or capoeiras of northern Brazil. It's distribution includes also Guianas, Venezuela, Paraguay and Bolivia and in Brazil extends from the Amazon to the east of Piauí, from central Brazil to the west of Paraná and south of Mato Grosso do Sul. ${ }^{15-18}$ It is noteworthy that this bird species is not considered as a regular campina bird species. ${ }^{8,19}$ The presence of $R$. carbo in our study area is probably associated to the recent history of disturbance on the surrounding landscape. Because these birds consumed the seeds and defected them intact, it is highly likely that they act as seed dispersers for $P$. guianensis. Another Rubiaceae flesh fruit, Faramea cyanea Mull. Arg. was studied in the gallery forest and in the cerradão in Brazil, ${ }^{20}$ and there was a predominance of omnivorous birds dispersers, followed by frugivorous and insectivorous. However, some relationships between fruit types and distribution did suggest that long distance dispersal has played a significant role in the biogeographical history of the
Rubiaceae. ${ }^{4}$ Drupes were over-represented among genera inhabiting "islands". For the authors, this suggests that possession of drupes might promote long-distance dispersal, which is essential for plants inhabiting patchy environments like white-sand ecosystems.

\section{Conclusion}

P. guianensis has as dispersing potential the bird Ramphocelus carbo.

\section{Acknowledgements}

This study is part of the master thesis of J. Alves (Capes grant).

\section{Conflict of interest}

None.

\section{References}

1. Daly DC, Prance GT. Floristic Inventory of Tropical Countries. In: Campbell DG, Hammond HD, editors. New York: Botanical Garden, Brazilian Amazon; 1989:400-426.

2. Junk WJ, Piedade MTF, Schöngart J, et al. A classification of major naturally-occurring Amazonian lowland wetlands. Wetlands. 2011;31(4):623-640.

3. Vicentini A. The Evolutionary History of Pagamea (Rubiaceae), a White-sand Specialist Lineage in Tropical South America. Biotropica. 2016;48(1):58-69.

4. Bremer B, Eriksson O. Evolution of fruit characters and dispersal modes in the tropical family Rubiaceae. Biological Journal of the Linnean Society. 1992;(47):79-95.

5. Oren DC. Zoogeographic analysis of the white sand campina avifauna of Amazonia. PhD dissertation, Massachusetts: Harvard University, Cambridge; 1981.

6. Alonso JA, Metz MR, Fine PVA. Habitat specialization by birds in western Amazonian white-sand forests. Biotropica. 2013;(45):365-372.

7. Borges SH. Bird species distribution in a complex Amazonian landscape: species diversity, compositional variability and biotic-environmental relationships. Studies in Neotropical Fauna and Environment. 2013;(48):106-118.

8. Borges SH, Cornelius C, Ribas C, et al. What is the avifauna of Amazonian white-sand vegetation? Bird Conservation International. 2016;(4):192-204.

9. Cordeiro N, Howe HF. Forest fragmentation severs mutualism between seed dispersers and an endemic African tree. Proceedings of the National Academy of Sciences of United States of America. 2003;100(24):14521456.

10. Howe HF, Miriti MN. When seed dispersal matters. Bioscience. 2004;54(7):651-660.

11. Jordano P, Godoy JA. Frugivore-generated seed shadows: a landscape view of demographic and genetic effects. In: Levey DJ, Silva WR, Galleti, M, editors. Seed dispersal and frugivory: ecology, evolution and conservation. 2002:305-321.

12. Saravy FP, Freitas PJ, Lage M. et al. Sindrome de Dispersão em extratos arbóreos em um fragmento de Floresta Ombrófila Aberta e Densa em Alta Floresta- MT. Alta Floresta. 2003;2(1):1-12.

13. Pizo MA. Seed dispersal and predation in two populations of Cabralea canjerana (Meliaceae) in the Atlantic Forest of southeastern Brazil. Journal of Tropical Ecology. 1997;13(4):559-578. 
14. Wotton DM, Kelly D. Do larger frugivores move seeds further? Body size, seed dispersal distance, and a case study of a large, sedentary pigeon. Journal of Biogeography. 2012;39:1973-1983.

15. Carvalho C. Notas sobre a biologia do Ramphocelus carbo (passeres: Thraupidae). Bol Mus Par, Emílio Goeldi, nova série, Zoologia. 1957;(5):1-20.

16. IUCN. Ramphocelus carbo. 2016.

17. Stotz DF, Fitzpatrick JW, Parker TA, et al. Neotropical Birds: Ecology and Conservation. Chicago: University of Chicago Press; 1996.
18. Uhrik K. Silver-beaked Tanager (Ramphocelus carbo). USA: Neotropical Birds; 2017.

19. Borges SH, Cornelius C, Moreira M, et al. Bird Communities in Amazonian White-Sand Vegetation Patches: Effects of Landscape Configuration and Biogeographic Context. Biotropica. 2016;48(1):121131.

20. Melo C, Bento EC, Oliveira PE. Frugivory and dispersal of Faramea cyanea (Rubiaceae) in Cerrado woody plant formations. Braz J Biol. 2003;63(1):75-82. 